\title{
COVID-19: CHALLENGES IN LONG-TERM CARE FACILITIES FOR OLDER ADULTS IN HISPANIC AMERICAN COUNTRIES
}

\section{Desafios da COVID-19 nas instituições de longa permanência para idosos em países hispano-americanos}

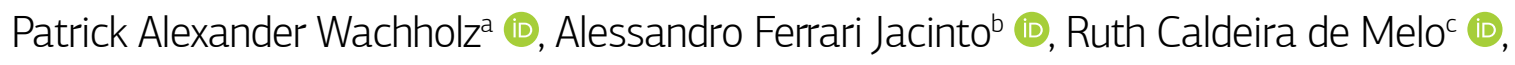 \\ José Luis Dinamarca-Montecinos ${ }^{d} \mathbb{D}$, Paulo José Fortes Villas Boas ${ }^{a}$ (i)
}

INTRODUCTION: Little is known about management and mitigation of COVID-19 in long-term care facilities (LTCF) for older adults in Latin America. OBJECTIVE: To describe how the management of LTCF in Hispanic American countries plan and adapt their routines for coping with COVID-19 and whether they have been able to fulfill recommendations published by the World Health Organization (WHO). METHODOLOGY: A cross-sectional study was conducted by online survey of managers of LTCF located in Hispanic American countries. A 46-item questionnaire (adopting the WHO principles) was sent to participants. Descriptive statistics were used to summarize the data. RESULTS: Twenty-three care home managers replied, responsible for a total of 874 older people (range: 5 - 270). One questionnaire was excluded because of missing responses. Fourteen LTCF (63.60\%) were private, for-profit facilities. The rate of compliance with WHO recommendations exceeded $70 \%$ for the majority of items. Just over half of the institutions had developed a strategic management plan, or had identified strategies for dealing with deaths of suspected cases. Difficulty acquiring personal protective equipment (PPE) was reported by $59.10 \%$ of the LTCF surveyed. The homes' capacity for SARS-Cov-2 testing was limited (36.36\% of the institutions did not have any tests). CONCLUSIONS: The rate of compliance with recommendations published by the WHO for dealing with COVID-19 was greater than 70\% at the majority of the LTCF surveyed. More than half of the institutions had strategic management plans. Availability of PPE and SARS-Cov-2 testing capacity were very unsatisfactory.

KEYWORDS: homes for the aged; aged; coronavirus infections.

INTRODUÇÃO: Pouco se sabe sobre o enfrentamento e a mitigação da COVID-19 em instituições de longa permanência para idosos (ILPIs) na América Latina. OBJETIVO: Descrever como os gestores de ILPIs de países hispano-americanos planejaram e adequaram suas rotinas de enfrentamento da COVID-19 e se foram capazes de cumprir as recomendações da Organização Mundial da Saúde (OMS). METODOLOGIA: Estudo transversal baseado na aplicação de uma pesquisa on-line dirigida aos gestores de ILPIs situadas em países hispano-americanos. Um questionário de 46 questões (adotando os princípios da OMS) foi enviado aos participantes. Estatística descritiva foi usada para resumir os dados. RESULTADOS: Vinte e três gestores responderam à pesquisa, totalizando 874 idosos (5 min - 270 máx); um questionário foi excluído por falta de respostas. Quatorze ILPIs (63,60\%) eram privadas com fins lucrativos. A taxa de adesão às recomendações da OMS foi superior a 70\% para a maioria das questões. Pouco mais da metade das instituições elaborou um plano estratégico de enfrentamento, ou identificou estratégias para lidar com óbitos de casos suspeitos. Dificuldade para a aquisição de equipamentos de proteção individual (EPIs) foi relatada por 59,10\% das ILPIs investigadas. A capacidade de testagem para o SARS-Cov-2 foi reduzida (36,36\% das instituições não dispunham de nenhum teste). CONCLUSÕES: A taxa de adesão às recomendações propostas pela OMS para o enfrentamento da COVID-19 foi superior a 70\% para a maioria das ILPIs investigadas. Planos estratégicos de enfrentamento foram elaborados em pouco mais da metade das instituições. A disponibilidade de EPIs e a capacidade de testagem para o SARS-Cov-2 mostraram-se bastante insatisfatórias.

PALAVRAS-CHAVE: instituição de longa permanência para idosos; idoso; infecções por coronavírus.

aDepartamento de Clínica Médica, Faculdade de Medicina de Botucatu, Universidade Estadual Paulista “Júlio de Mesquita Filho” - Botucatu (SP), Brasil.

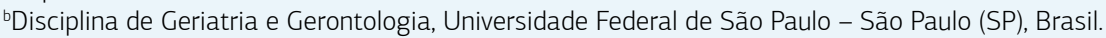

'Escola de Artes, Ciências e Humanidades, Universidade de São Paulo - São Paulo (SP), Brasil.

${ }^{d}$ Cátedra de Traumatologia y Ortopedia, Cátedra de Medicina Interna, Universidad de Valparaíso - Valparaíso, Chile.

Dados para correspondência

Patrick Alexander Wachholz - Faculdade de Medicina, Universidade Estadual Paulista "Júlio de Mesquita Filho" - Avenida Professor Mário Rubens Guimarães Montenegro, s/n - Rubião Júnior - CEP: 18618-687 - Botucatu (SP), Brasil. E-mail: patrick.wachholz@unesp.br

Recebido em: 15/07/2020. Aceito em: 02/09/2020

https://doi.org/10.5327/Z2447-212320202000085

Articles in Geriatrics, Gerontology and Aging are published under the terms of the Creative Commons Attribution-NonCommercial-NoDerivatives 4.0 International License (CC-BY-NC-ND 4.0), which permits use, distribution and reproduction in any medium, provided that the article is properly cited, the use is non-commercial and no modifications or adaptations are made. 


\section{INTRODUCTION}

Latin America encompasses the part of the American continent made up of countries that speak Romance languages, because they were colonized, in their majority, by Portugal and Spain. Its geographical area accounts for more than $14 \%$ of the land surface of the globe and it is highly heterogeneous in terms of the demographic, political, economic, and social characteristics of the countries within it. ${ }^{1,2}$

Although the proportions of the population over the age of 65 years in the different Latin American countries are similar (only Argentina, Chile, and Uruguay have proportions greater than or equal to $15 \%),{ }^{2}$ the impact of the COVID-19 pandemic has been felt more significantly in countries with worse social inequality indicators and in those where the governmental response to this emerging threat has been insufficient or confrontational..$^{3-5}$

After the first officially recorded case of COVID-19 in the region, at the end of February 2020, the deficient healthcare systems in the majority of these countries (a considerable proportion of which were already battered by recent outbreaks of chikungunya, dengue, yellow fever, and zika) ${ }^{5}$ were severely impacted by the sudden increase in demand for hospitalization and, in particular, for intensive care beds. ${ }^{6-8}$

Before the pandemic, the majority of Hispanic American countries were already finding it difficult to deal with the increasing demand for long-term care for older people. ${ }^{9}$ Ineffective public policies and insufficient investment, low quality long-term care (when compared with high-income countries), and fragile health systems were suddenly faced with a highly transmissible virus. ${ }^{10}$ Compounded by the region's insufficient capacity for detection of and testing for the virus, infections proved to be potentially lethal in the more fragile and vulnerable segments of the population, ${ }^{11-13}$ in particular among the residents of long-term care facilities (LTCF) for the older adults. ${ }^{14}$

On March 21, 2020, the World Health Organization (WHO) published guidelines for infection prevention and control in LTCF in the context of COVID-19. ${ }^{15}$ Its primary messages were later revised and included in recommendations published by the United States' Centers for Disease Control and Prevention (CDC). ${ }^{16} \mathrm{~A}$ little more than 2 months later, on June 9, 2020, the Pan American Health Organization (PAHO) declared that Latin America was the new epicenter of the global COVID-19 pandemic. $^{17}$

The impact of COVID-19 in LTCF can be observed via the incidence of outbreaks and the large numbers of deaths in a short period, which were revealed by both official and unofficial sources. ${ }^{12,18}$ In countries such as Canada, Slovenia, Belgium, and Ireland, older people resident in LTCF account for more than $50 \%$ of total mortality from COVID-19. ${ }^{12}$ In Spain, $45 \%$ of the total excess mortality from March 20 to May 30, 2020 , and $55 \%$ of excess mortality among people more than 74 years old, occurred in homes for older people: these deaths equated to $6.10 \%$ of all rest home residents in the country. ${ }^{18}$

Against this background, understanding how the LTCF in Hispanic American countries have responded to the threat inherent in COVID-19 should be useful for developing strategies for responding to, coping with, and mitigating the pandemic.

Adopting the WHO guidelines ${ }^{15}$ the objective of this study is to describe how the management of LTCF in Hispanic American countries planned, executed, and adapted their routines for coping with the COVID-19 pandemic and whether they were able to comply with these recommendations.

\section{METHODS}

This is a cross-sectional, observational study based on administration of an on-line survey to the management of LTCF in Hispanic American countries . A 46-item questionnaire, in Spanish, was developed according to the principles of the WHO guidelines. ${ }^{15}$ The questionnaire was constructed using Google Forms, an app for managing surveys launched by Google. Participants were recruited using sites and social network applications after identification by scientific societies and geriatrics specialists based in Hispanic American countries.

The survey was anonymous and confidential. Participants were only allowed to complete the instrument once and were permitted to stop whenever they wished. It was established, a priori, that if fewer than $50 \%$ of items were answered, the respondent's entire questionnaire would be excluded from the analysis.

Data were collected from May 5 to June 20,2020. The study was approved by the National Research Ethics Commission (CONEP - Comissão Nacional de Ética em Pesquisa), decision number: 30577520.0.0000.0008.

Descriptive statistics were used to summarize the data, using measures of central tendency (mean, median, and mode), dispersal (range, standard deviation, and variance), and distribution.

\section{RESULTS}

Twenty-three managers of LTCF in Hispanic America answered the survey. One of the respondents only provided answers to the first ten items, so the questionnaire was excluded from the analysis. 
Six of the LTCF participants were from Chile, four were from Mexico, and three were from Peru. There were two LTCF from each of Costa Rica and Argentina and one LTCF from each of El Salvador, Colombia, Bolivia, Ecuador, and Uruguay. The total population cared for at the 22 facilities was 874 older people (range: 5 - 270), with a median of 24.50 (interquartile range $[\mathrm{IQR}]=19-75)$. With regard to their institutional nature, 14 LTCF (63.60\%) were private for-profits (one was subsidized by government), while eight were philanthropic. No public LTCFs replied to invitations to participate in the survey.

Scientific societies and the local government were the primary sources of information used by 18 (81.90\%) LTCF to prepare for the COVID-19 pandemic. Eleven respondents (50\%) stated that they had not received any type of external support or financial subsidies to help them cope with the pandemic. When these LTCF identified suspected or confirmed cases of infection, the local authorities most frequently notified were governmental organs (including health and epidemiological surveillance agencies) $(n=13)$, followed by the local operational support center for COVID-19 $(n=11)$, and the Public Prosecutor $(n=8)$.

The data that follow are presented in three sections, respecting their distribution in the WHO guidelines: ${ }^{15}$

- coordination to provide long-term care;

- prevention;

- response and notification.

Tables 1 to 3 show the responses (with their respective percentages) to the recommendations in each of the sections listed above.
All of the LTCF reported using disposable gloves, alcohol gel, and basins with soap and water for hand washing. Face screens, disposable masks, and washable aprons were mentioned by 16 (72.72\%) LTCF, while three (13.63\%) also provided antifluids coveralls. Impermeable boots were available at nine facilities (40.90\%), whereas shoe covers and protective glasses were only mentioned by two. Masks with N95 rating were available at two LTCF (9.09\%). One facility stated that it used a disinfection tunnel and chemical mats.

The time that stocks of personal protective equipment (PPE) were predicted to last was less than 1 week at $18.20 \%$ $(n=9)$ of the LTCF, from 2 to 4 weeks at $50 \%(n=11)$, and more than 5 weeks at $27.20 \%(n=6)$. One respondent stated that there were already PPE shortages. Thirteen managers (59.10\%) confirmed that they were having difficulties buying or maintaining their stocks of PPE and cleaning materials.

According to the respondents, the time needed to prepare their institutions to cope with the pandemic was 15 days. In the event that a similar situation occurred again in the future, they estimated that they would need an average of 13.10 days $( \pm 9.02)$ to prepare adequately.

\section{DISCUSSION}

The rate of LTCF compliance with recommendations for dealing with COVID-19 proposed by the WHO was greater than $70 \%$ for the majority of items. A little more than half of the institutions were able to develop a strategic management plan for the disease and, in particular, identify

Table 1. Compliance with World Health Organization recommendations for provision of contacts and coordination of care for COVID-19 in long-term care facilities for older adults in Hispanic American countries ( $n=22)$.

\begin{tabular}{|c|c|c|}
\hline Recommendation & Response & $n(\%)$ \\
\hline $\begin{array}{l}\text { The institution constantly monitors publication of new public recommendations on } \\
\text { COVID-19, considering the possibility of adapting or modifying its action plan. }\end{array}$ & $\begin{array}{l}\text { Yes } \\
\text { No } \\
\text { Partially }\end{array}$ & $\begin{array}{l}21(95.45) \\
1(4.55) \\
\quad 0(0)\end{array}$ \\
\hline $\begin{array}{l}\text { Cases of residents with fever or respiratory symptoms were promptly reported to those } \\
\text { responsible for clinical care at the LTCF, or to the local health authority responsible for } \\
\text { monitoring suspected COVID-19 cases. }\end{array}$ & $\begin{array}{l}\text { Yes } \\
\text { No }\end{array}$ & $\begin{array}{l}21(95.45) \\
1(4.55)\end{array}$ \\
\hline $\begin{array}{l}\text { A contingency plan was implemented to determine the minimum number of workers } \\
\text { necessary for the institution to operate safely and how to contract or recruit additional } \\
\text { personnel, if needed. }\end{array}$ & $\begin{array}{l}\text { Yes } \\
\text { No } \\
\text { Partially }\end{array}$ & $\begin{array}{l}20 \text { (90.91) } \\
0(0) \\
2(9.09)\end{array}$ \\
\hline $\begin{array}{l}\text { A contingency plan was drawn up to deal with any cases of deaths at the facility (for } \\
\text { example, designation of a specific area for bodies and any material/furniture that could have } \\
\text { become contaminated, reducing the likelihood of contamination of other residents, workers, } \\
\text { and visitors). }\end{array}$ & $\begin{array}{l}\text { Yes } \\
\text { No } \\
\text { Partially }\end{array}$ & $\begin{array}{l}10(45.45) \\
7(31.82) \\
5(22.73)\end{array}$ \\
\hline $\begin{array}{l}\text { The facility has set up protocols for contingencies and care flows for transfer of suspected } \\
\text { cases in conjunction with local health authorities, primary care health centers, a tertiary } \\
\text { hospital, or mobile emergency services. }\end{array}$ & $\begin{array}{l}\text { Yes } \\
\text { No } \\
\text { Partially }\end{array}$ & $\begin{aligned} 17 & (77.27) \\
1 & (4.55) \\
4 & (18.18)\end{aligned}$ \\
\hline
\end{tabular}

LTCF: long-term care facilities for the aged. 
strategies for reducing risk of contamination after death of suspected cases. The lack of PPE and difficulties acquiring PPE were relevant concerns for almost $60 \%$ of the LTCF investigated. Moreover, the capacity for SARS-Cov-2 testing was also limited in this sample.

Brazil was the first country in Latin America to report a case of COVID-19, in February 2020. ${ }^{5}$ SARS-CoV-2 rapidly propagated throughout all of the countries in the region, repeating in Latin America the pattern of higher morbidity among potentially vulnerable populations that had occurred in other countries. ${ }^{8,13}$ However, differently, population groups even more susceptible to the threat were observed, including indigenous communities, and also a higher proportion of people living in poverty, and multigenerational households, exposed to healthcare systems with lower financial capacity and ability to respond to overload from demand for care.

Latin America is very diverse in socioeconomic terms, and the composition, organization, and structure of local healthcare systems are also highly varied. The capacity to respond to and deal with emerging public health threats, such as COVID-19, competes for finance, medications, and hospital beds with other recurrent epidemics, such as, for example, dengue.

Regional surveys regarding COVID-19 are very useful, have the potential to benefit populations in other countries, and, possibly, provide evidence to enable regional organizations (such as PAHO) to make recommendations to the extent that countries implement social distancing strategies and avoid a second wave, when social isolation or quarantine recommendations are suspended. ${ }^{11}$

At the start of the pandemic, Guatemala and Haiti combined had fewer than 100 ventilators to support severe cases of respiratory failure, as can occur in COVID-19. ${ }^{5}$ In addition to difficulty with providing care for severe cases, the great majority of Latin American countries have limited capacity for adopting infection screening and testing strategies. ${ }^{11}$

Table 2. Compliance with World Health Organization recommendations for prevention of COVID-19 contagion in long-term care facilities for older adults in Hispanic American countries $(n=22)$.

\begin{tabular}{|c|c|c|}
\hline Recommendation & Response & n (\%) \\
\hline $\begin{array}{l}\text { Infection prevention and control training was provided to all employees, including as a } \\
\text { minimum the topics recommended by the WHO. }\end{array}$ & $\begin{array}{l}\text { Completed } \\
\text { Ongoing } \\
\text { Not done }\end{array}$ & $\begin{array}{l}17(77.27) \\
5(22.73) \\
0(0)\end{array}$ \\
\hline $\begin{array}{l}\text { Information sessions on COVID-19 were provided for residents able to understand to, } \\
\text { as a minimum, inform them about the virus, symptoms, and causes and how to protect } \\
\text { themselves from infection. }\end{array}$ & $\begin{array}{l}\text { Completed } \\
\text { Ongoing } \\
\text { Not done }\end{array}$ & $\begin{array}{l}16(72.73) \\
4(18.18) \\
2(9.09)\end{array}$ \\
\hline $\begin{array}{l}\text { Infection prevention and control and hygiene practices are regularly audited and feedback is } \\
\text { provided to employees. }\end{array}$ & $\begin{array}{l}\text { Yes } \\
\text { No } \\
\text { Partially }\end{array}$ & $\begin{array}{l}19(86.36) \\
3(13.64) \\
0(0)\end{array}$ \\
\hline $\begin{array}{l}\text { Annual influenza vaccination (seasonal influenza and } \mathrm{H} 1 \mathrm{~N} 1 \text { ) and pneumococcal vaccines } \\
\text { (according to local policies) are provided to employees and residents. }\end{array}$ & $\begin{array}{l}\text { Completed } \\
\text { Ongoing } \\
\text { Not done }\end{array}$ & $\begin{array}{c}19(86.36) \\
3(13.64) \\
0(0)\end{array}$ \\
\hline $\begin{array}{l}\text { For group activities recommended physical distancing was ensured or, if not feasible, group } \\
\text { activities were canceled. }\end{array}$ & $\begin{array}{c}\text { Yes } \\
\text { No } \\
\text { Partially }\end{array}$ & $\begin{array}{c}21(95.45) \\
1(4.55) \\
0(0)\end{array}$ \\
\hline $\begin{array}{l}\text { Meals were staggered to ensure minimum physical distance or, if not feasible, residents are } \\
\text { being served in their rooms. }\end{array}$ & $\begin{array}{c}\text { Yes } \\
\text { No } \\
\text { Partially }\end{array}$ & $\begin{array}{c}17(77.27) \\
3(13.64) \\
2(9.09)\end{array}$ \\
\hline $\begin{array}{l}\text { Residents and employees have been instructed to avoid touching and guidance on the } \\
\text { importance of minimum distance is constantly reiterated. }\end{array}$ & $\begin{array}{c}\text { Yes } \\
\text { No } \\
\text { Partially }\end{array}$ & $\begin{array}{c}22(100) \\
0(0) \\
0(0)\end{array}$ \\
\hline $\begin{array}{l}\text { Posters and flyers have been posted to remind residents and employees about physical } \\
\text { distancing and contagion prevention recommendations. }\end{array}$ & $\begin{array}{c}\text { Yes } \\
\text { No } \\
\text { No Response }\end{array}$ & $\begin{array}{c}17(77.27) \\
4(18.18) \\
1(4.55)\end{array}$ \\
\hline $\begin{array}{l}\text { All visitors have been at least questioned and/or screened for signs and symptoms of acute } \\
\text { respiratory infection or significant risk for COVID-19, and no one with signs or symptoms has } \\
\text { been allowed to enter the premises. }\end{array}$ & $\begin{array}{l}\text { Yes } \\
\text { No }\end{array}$ & $\begin{array}{l}19(86.36) \\
3(13.64)\end{array}$ \\
\hline
\end{tabular}

WHO: World Health Organization. 
Table 3. Compliance with World Health Organization recommendations for early recognition, isolation, care, and control of infection in response to COVID-19 at long-term care facilities for older adults in Hispanic American countries $(n=22)$.

\begin{abstract}
Recommendation
During the pandemic period, the health status of any new residents was assessed before admission to determine if the resident has signs of a respiratory illness or no new admissions were accepted.
\end{abstract}

Each resident has been assessed regularly (ideally twice daily) for presence of a fever, cough, or shortness of breath.

Employees have been asked and encouraged to report and stay at home if they have fever or any respiratory illness.

Workers with unexplained absences have been followed-up and given active support (by telephone, for example), and also their family members, to determine whether they had symptoms of infection, particularly if there has been known contact with suspected or confirmed COVID-19 cases.

Employees' temperatures have been checked at the facility entrance and visibly ill workers have been referred for medical assessment.

A contingency plan was implemented to determine the minimum number of workers necessary for the institution to operate safely and how to contract or recruit additional personnel.

The institution now has infrastructure available for respiratory isolation of suspected cases, enabling the needs of older people with symptoms to be met and workers to take precautionary measures.

The LTCF has set up a multidisciplinary planning committee to decide and/or discuss plans for COVID-19 infection prevention and control.

The LTCF has drawn up in writing a strategic plan for coping with COVID-19.

Workers and residents have access to PPE.

Does the LTCF have access to laboratory tests to confirm coronavirus (and/or influenza) infection in suspected cases?

\begin{tabular}{|c|c|c|}
\hline $\begin{array}{l}\text { When caring for any residents with suspected or confirmed COVID-19, provision of PPE for } \\
\text { workers is guaranteed, and all contact and airborne precautions are adopted. }\end{array}$ & $\begin{array}{l}\text { Yes } \\
\text { No } \\
\text { Partially }\end{array}$ & $\begin{array}{l}21(95.45) \\
0(0) \\
1(4.55)\end{array}$ \\
\hline $\begin{array}{l}\text { Employees were instructed and constantly reminded to appropriately take off PPE just after } \\
\text { leaving a room where they have cared for a suspected/confirmed case and to discard it in } \\
\text { an appropriate place and perform hand hygiene. }\end{array}$ & $\begin{array}{l}\text { Yes } \\
\text { No } \\
\text { Partially }\end{array}$ & $\begin{array}{l}21(95.45) \\
0(0) \\
1(4.55)\end{array}$ \\
\hline $\begin{array}{l}\text { Workers, residents, and relatives were informed that residents with suspected or confirmed } \\
\text { COVID-19 cannot leave their rooms while still sick. }\end{array}$ & $\begin{array}{l}\text { Yes } \\
\text { No } \\
\text { Partially }\end{array}$ & $\begin{array}{l}20(90.91) \\
0(0) \\
2(9.09)\end{array}$ \\
\hline $\begin{array}{l}\text { Suspected cases were kept isolated until two negative laboratory tests for COVID-19 with } \\
\text { at least a } 24 \text {-hour interval (when available within the local healthcare system), or until all } \\
\text { symptoms have resolved (minimum of } 14 \text { days). }\end{array}$ & $\begin{array}{l}\text { Yes } \\
\text { No } \\
\text { Partially }\end{array}$ & $\begin{aligned} 19 & (86.36) \\
2 & (9.09) \\
1 & (4.55)\end{aligned}$ \\
\hline
\end{tabular}

LTCF: long-term care facility for the aged; PPE: personal protective equipment.

\begin{tabular}{|c|c|}
\hline Response & n (\%) \\
\hline $\begin{array}{l}\text { Yes } \\
\text { No }\end{array}$ & $\begin{array}{c}18(81.82) \\
4(18.18)\end{array}$ \\
\hline $\begin{array}{c}\text { Yes } \\
\text { No } \\
\text { Partially }\end{array}$ & $\begin{array}{c}20(90.91) \\
0(0) \\
2(9.09)\end{array}$ \\
\hline $\begin{array}{l}\text { Yes } \\
\text { No }\end{array}$ & $\begin{array}{c}22(100) \\
0(0)\end{array}$ \\
\hline $\begin{array}{c}\text { Yes } \\
\text { No } \\
\text { Partially } \\
\text { No response }\end{array}$ & $\begin{array}{c}17(77.27) \\
3(13.63) \\
1(4.55) \\
1(4.55)\end{array}$ \\
\hline $\begin{array}{c}\text { Yes } \\
\text { No } \\
\text { Partially }\end{array}$ & $\begin{array}{c}19(86.36) \\
1(4.55) \\
2(9.09)\end{array}$ \\
\hline $\begin{array}{c}\text { Yes } \\
\text { No } \\
\text { Partially }\end{array}$ & $\begin{array}{c}20(90.91) \\
0(0) \\
2(9.09)\end{array}$ \\
\hline $\begin{array}{c}\text { Yes } \\
\text { No } \\
\text { Partially }\end{array}$ & $\begin{array}{c}17(77.27) \\
1(4.55) \\
4(18.18)\end{array}$ \\
\hline $\begin{array}{l}\text { Yes } \\
\text { No }\end{array}$ & $\begin{array}{c}13 \text { (59.09) } \\
9(40.91)\end{array}$ \\
\hline $\begin{array}{l}\text { Completed } \\
\text { Ongoing } \\
\text { Not started }\end{array}$ & $\begin{array}{c}12(54.54) \\
7(31.82) \\
3(13.64)\end{array}$ \\
\hline $\begin{array}{c}\text { Yes } \\
\text { No } \\
\text { Partially }\end{array}$ & $\begin{array}{c}20(90.91) \\
0(0) \\
2(9.09)\end{array}$ \\
\hline $\begin{array}{l}\text { SARS-COv-2 } \\
\text { Influenza } \\
\text { Both } \\
\text { Neither } \\
\text { No response }\end{array}$ & $\begin{array}{l}7(31.82) \\
2(9.09) \\
3(13.64) \\
8(36.36) \\
2(9.09)\end{array}$ \\
\hline $\begin{array}{c}\text { Yes } \\
\text { No } \\
\text { Partially }\end{array}$ & $\begin{array}{c}21(95.45) \\
0(0) \\
1(4.55)\end{array}$ \\
\hline $\begin{array}{c}\text { Yes } \\
\text { No } \\
\text { Partially }\end{array}$ & $\begin{array}{c}21(95.45) \\
0(0) \\
1(4.55)\end{array}$ \\
\hline $\begin{array}{c}\text { Yes } \\
\text { No } \\
\text { Partially }\end{array}$ & $\begin{array}{c}20(90.91) \\
0(0) \\
2(9.09)\end{array}$ \\
\hline $\begin{array}{c}\text { Yes } \\
\text { No } \\
\text { Partially }\end{array}$ & $\begin{array}{c}19(86.36) \\
2(9.09) \\
1(4.55)\end{array}$ \\
\hline
\end{tabular}


Although several countries have produced guidelines for early management of the COVID-19 pandemic, up to the end of March, few Latin American countries had guidelines for preventative and control measures specifically for LTCF. ${ }^{19}$

In line with what is happening in the rest of the world, the populations in Latin America are aging rapidly. The inherent conditions of the age group mean that care provided by LTCF is increasingly required. ${ }^{20}$ LTCF are high-risk environments for occurrence of negative and severe outcomes during COVID-19 outbreaks, whether because of the advanced age of their residents, because of the profile of multiple comorbidities and functional dependence, or because of movement of health professionals between the facilities of a given region. ${ }^{21,22}$

Reports of outbreaks of the disease in LTCF multiplied all over the world, ${ }^{10,12,18,22-24}$ in general with lethality significantly higher than in other age groups and populations. ${ }^{12}$ Preventative actions and support for LTCF are thus understood as essential in scenarios such as COVID-19. ${ }^{25}$

Despite the low response rate, LTCF from ten different countries responded to the questionnaire. In general terms, they described being aligned with WHO recommendations for managing the COVID-19 pandemic. ${ }^{15}$ More than half had not drawn up a contingency plan for dealing, for example, with any cases of deaths at the facility, which is understandable, since changes related to making infrastructure available are not a task that is easy to achieve in a short time.

As has been observed in other countries, the LTCF are poorly equipped to prevent propagation of the virus. They do not have the financial or technical resources, including tests and PPE, to contain the pandemic. The care teams that work at these facilities are, in general, poorly paid and poorly trained. ${ }^{26}$

Although the guidelines initially only recommended isolation of symptomatic residents and workers, it was rapidly observed that more than half of residents who had positive laboratory test results for SARS-Cov- 2 were asymptomatic at the time of the test and may have contributed to transmission. ${ }^{27} \mathrm{It}$ is therefore improbable that these initial measures, alone, successfully prevented propagation of COVID-19 in LTCF. The scarcity of testing availability for LTCF is not, however, exclusive to Latin American countries, since it was also a factor in the outbreaks that decimated hundreds of older people living in LTCF in Europe. ${ }^{23,24,28}$

The lack of PPE and difficulty acquiring PPE increases even further the risk of outbreaks occurring in LTCF. Both these conditions, compounded by the increased rates of absenteeism among LTCF workers caused by contamination and the poor capacity for laboratory testing in the region, possibly drove the elevated lethality rates in the sector.
While discussions are ongoing about the best route to relaxing restrictions on visiting LTCF, bearing in mind that one of the most important measures recommended was that they be suspended, it is urgent to provide this sector with better structured support for coping with the pandemic, which is an essential measure for reducing the lethality observed so far.

This study has limitations restricting generalization of the findings. Although steps were taken to achieve better coverage of Hispanic American countries (including sending invitations by e-mail to more than 500 addresses provided by professionals, scientific societies, and governmental and non-governmental organizations), the percentage of responses was low. Similarly, this recruitment strategy also favors private $\mathrm{LTCF}$ and those with better financial status, who have an administrator and access to the internet. This is, however, far from being the rule at facilities in Latin America, which probably has one of the highest proportions of unofficial and unregistered care homes in the world.

In addition to the limitations inherent to the cross-sectional design and sample size, use of dichotomous response options, rather than interval scales (Likert scales, for example), possibly introduces response bias. ${ }^{29}$

The COVID-19 pandemic has affected Hispanic American countries differently. So far, while Ecuador, Peru, and Bolivia have had very high rates of dissemination and mortality, other countries, such as Uruguay, Colombia, Panama, and Chile have been relatively successful at controlling propagation of infection, even in long-term care settings.

Construction of strategies to reduce the impact of a second or third wave of contamination in Latin America, particularly in long-term care settings, should prioritize information and correct use of scientific evidence. Development of strategic management plans and implementation of strategies for screening for and detection of contamination will be key.

\section{CONCLUSIONS}

Public health crises are devastating for the vulnerable populations of low and middle income countries, particularly when the enemy is an emerging infection about which little is yet known and for which there are no effective treatments.

Implementation of effective strategies for protection of the most vulnerable segments is dependent on rapid and correct adoption of the best available evidence. The debilitated healthcare information systems in Latin America are just one of the fragile links that hamper adoption of measures and more rapid responses in the long-term care for older people sector. Recognition of the characteristics of the response of LTCF to COVID-19 is, therefore, essential. 
The rate of compliance with recommendations for coping with COVID-19 proposed by the $\mathrm{WHO}$ was greater than $70 \%$ at the majority of the LTCF investigated.Just over half of the institutions were able to develop strategic management plans for the disease, despite the high rate of compliance with recommendations. Along the same lines, availability of PPE was highly unsatisfactory.

\section{CONFLICTS OF INTEREST}

The authors have no conflict of interests to declare.

\section{FUNDING}

None.

\section{AUTHORS' CONTRIBUTION}

PAW: conceptualization, data curation, formal analysis, investigation, methodology, project administration, resources, supervision, validation, visualization, writing original draft, writing - review \& editing. RCM: conceptualization, investigation, methodology, visualization, writing — original draft, writing — review \& editing. AFJ: conceptualization, formal analysis, writing — original draft, writing — review \& editing. PJFVB: conceptualization, data curation, formal analysis, writing - original draft, writing - review \& editing. JLDM: investigation, resources, visualization, writing - original draft, writing — review \& editing. PJFVB: visualization, writing — original draft, writing — review \& editing.

\section{REFERENCES}

1. United Nations. World economic situation and prospects 2015. Nova York: United States; 2015. Available from: https://www.un.org/en/ development/desa/policy/wesp/wesp_archive/2015wesp_full_en.pdf. Accessed in Jul 4, 2020.

2. United Nations. Department of Economics and Social Affairs. World Population Prospects 2019. Available from: https://population.un.org/ wpp/Maps/. Accessed in Jul 4, 2020.

3. Cimerman S, Chebabo A, Cunha CA da, Rodríguez-Morales AJ. Deep impact of COVID-19 in the healthcare of Latin America: the case of Brazil. Brazilian Journal of Infectious Diseases [Internet]. 2020 [Accessed in 2020 Jul 4];24(2):93-5. Available in: http://bjid.elsevier.es/en-deepimpact-covid-19-in-healthcare-articulo-S1413867020300325. http:// doi.org/10.1016/j.bjid.2020.04.005

4. United Nations. Report on the economic impact of coronavirus disease (COVID-19) on Latin America and the Caribbean. United Nations; 2020. Available from: https://www.cepal.org/en/publications/45603-reporteconomic-impact-coronavirus-disease-covid-19-latin-america-andcaribbean. Accessed in Jul 4, 2020.

5. Burki T. COVID-19 in Latin America. Lancet Infect Dis [Internet]. 2020 [Accessed in $2020 \mathrm{Jul}$ 4];20(5):547-8. Available in: https:// pubmed.ncbi.nlm.nih.gov/32311323/. https://doi.org/10.1016/s14733099(20)30303-0

6. Rodriquez-Morales AJ, Gallego V, Escalera-Antezana JP, Méndez CA, Zambrano LI, Franco-Paredes C, et al. COVID-19 in Latin America: The implications of the first confirmed case in Brazil. Travel Med Infect Dis [Internet]. 2020 [Accessed in $2020 \mathrm{Jul}$ 4];35:101613. Available in: https://pubmed.ncbi.nlm.nih.gov/32126292/. https://doi.org/10.1016/j. tmaid.2020.101613

7. Sánchez-Duque JA, Arce-Villalobos LR, Rodríguez-Morales AJ. Coronavirus disease 2019 (COVID-19) in Latin America: Role of primary care in preparedness and response. Aten Primaria [Internet]. 2020 [Accessed in $2020 \mathrm{Jul}$ 4];52(6):369-72. Available in: https:// pubmed.ncbi.nlm.nih.gov/32386927/. https://doi.org/10.1016/j. aprim.2020.04.001

8. Andrus JK, Evans-Gilbert T, Santos JI, Guzman MG, Rosenthal PJ, Toscano C, et al. Perspectives on Battling COVID-19 in Countries of Latin America and the Caribbean. Am J Trop Med Hyg [Internet]. 2020 [Accessed in $2020 \mathrm{Jul}$ 4];103(2):593-6. Available in: https:// pubmed.ncbi.nlm.nih.gov/32524963/. https://doi.org/10.4269/ ajtmh.20-0571

9. Cafagna G, Aranco N, Ibarrarán P, Medellín N, Oliveri ML, Stampini M. Envejecer con cuidado: Atención a la dependencia en América Latina y el Caribe. Inter-American Development Bank; 2019. Available from: https://publications.iadb.org/es/envejecer-con-cuidado-atencion-ladependencia-en-america-latina-y-el-caribe. Accessed in Apr 5, 2020. http://doi.org/10.18235/0001972

10. Kimball A, Hatfield KM, Arons M, James A, Taylor J, Spicer K, et al. Asymptomatic and Presymptomatic SARS-CoV-2 Infections in Residents of a Long-Term Care Skilled Nursing Facility - King County, Washington March 2020. MMWR Morb Mortal Wkly Rep [Internet]. 2020 [Accessed in 2020 Apr 5];69(13):377-81. Available in: http://www.cdc.gov/mmwr/ volumes/69/wr/mm6913e1.htm?s_cid=mm6913e1_w. http://doi. org/10.15585/mmwr.mm6913e1

11. Carrillo-Larco RM. COVID-19 data sources in Latin America and the Caribbean. Travel Med Infect Dis [Internet]. 2020 [Accessed in $2020 \mathrm{Ju}$ 4];101750. Available in: https://pubmed.ncbi.nlm.nih.gov/32479817/. https://doi.org/10.1016/j.tmaid.2020.101750

12. Comas-Herrera A, Zalakain J. Mortality associated with COVID-19 outbreaks in care homes: early international evidence. Resources to support community and institutional Long-Term Care responses to COVID-19. Ontário; 2020. Available from: https://www.ontario.ca/ page/how-ontario-is-responding-covid-19\#section-1. Accessed in Jun 29, 2020.

13. Roser M, Ritchie $H$, Ortiz-Ospina E. Case fatality rate of the ongoing COVID-19 pandemic [Internet]. Our World in Data; 2020. Available from: https://ourworldindata.org/grapher/coronaviruscfr?country=ITA KOR OWID_WRL DEU ISL $\sim$ BRA USA GBR Upper middle income CAN FRA. Accessed in Jul 3, 2020.

14. Sociedade Brasileira de Geriatria e Gerontologia. Manual de Funcionamento: instituições de longa permanência para idosos. São Paulo: Sociedade Brasileira de Geriatria e Gerontologia; 2003.

15. World Health Organization. Infection Prevention and Control guidance for Long-Term Care Facilities in the context of COVID19. Interim Guidance. Health Organization; 2020. Available from: https://apps.who.int/iris/handle/10665/331508. Accessed in Jul 4, 2020

16. Centers for Disease Control and Prevention. Preparing for COVID-19 in Nursing Homes. Centers for Disease Control and Prevention; 2020. Available from: https://www.cdc.gov/coronavirus/2019-ncov/hcp/longterm-care.html. Accessed in Jul 4, 2020.

17. Ponchner D. Latin America Faces a Critical Moment in the Battle against COVID-19. Sci Am [Internet]. 2020 [Accessed in 2020 Jul 4]. Available in: https://www.scientificamerican.com/article/latin-americafaces-a-critical-moment-in-the-battle-against-covid-19/ 
18. Salcher-Konrad M, Jhass A, Naci H, Tan M, El-Tawil Y, Comas-Herrera A. COVID-19 related mortality and spread of disease in long-term care: first findings from a living systematic review of emerging evidence. medRxiv [Internet]. 2020 [Accessed in 2020 Jul 4];2020.06.09.20125237. Available in: https://doi.org/10.1101/2020.06.09.20125237

19. Comas-Herrera A, Fernández J-L. Summary of international policy measures to limit impact of COVID-19 on people who rely on the Long-Term Care sector. 2020.

20. Wachholz PA, Jacinto AF. Comment on: Coronavirus Disease 2019 in Geriatrics and Long-Term Care: The ABCDs of COVID-19. J Am Geriatr Soc. 2020;68(6):1168-9. https://doi.org/10.1111/jgs.16551

21. McGilton KS, Heath $\mathrm{H}$, Chu CH, Boström AM, Mueller C, Boscart VM, et al. Moving the agenda forward: A person-centred framework in long-term care. Int J Older People Nurs. 2012;7(4):303-9. https:// doi.org/10.1111/opn.12010

22. McMichael TM, Currie DW, Clark S, Pogosjans S, Kay M, Schwartz NG, et al. Epidemiology of covid-19 in a long-term care facility in King County, Washington. N Engl J Med. 2020;382(21):2005-11. https:// doi.org/10.1056/nejmoa2005412

23. Porcheddu R, Serra C, Kelvin D, Kelvin N, Rubino S. Similarity in Case Fatality Rates (CFR) of COVID-19/SARS-COV-2 in Italy and China. J Infect Dev Ctries [Internet]. 2020 [Accessed in 2020 Mar 23];14(2):125-8. Available in: http://www.ncbi.nlm.nih.gov/pubmed/32146445. https:// doi.org/10.3855/jidc.12600
24. Remuzzi A, Remuzzi G. COVID-19 and Italy: what next? The Lancet. 2020;395(10231):1225-8. https://doi.org/10.1016/S01406736(20)30627-9

25. Watanabe HAW, Domingues MAR da C, Duarte YA de O. COVID-19 e as Instituições de Longa Permanência para Idosos: cuidado ou morte anunciada? Geriatr Gerontol Aging [Internet]. 2020 [Accessed in 2020 Jul 9];14(2)143-5. Available in: https://doi.org/10.5327/ Z2447-2123202020142LTTR

26. Werner RM, Hoffman AK, Coe NB. Long-Term Care Policy after Covid-19 - Solving the Nursing Home Crisis. N Engl J Med [Internet] 2020 [Accessed in $2020 \mathrm{Jul}$ 9];383:903-5. Available in: https://www. nejm.org/doi/full/10.1056/NEJMp2014811. https://doi.org/10.1056/ NEJMp2014811

27. Arons MM, Hatfield KM, Reddy SC, Kimball A, James A, Jacobs JR, et al. Presymptomatic SARS-CoV-2 Infections and Transmission in a Skilled Nursing Facility. N Engl J Med [Internet]. 2020 [Accessed in 2020 Jul 9];382:2081-90. Available in: http://www.nejm.org/doi/10.1056/ NEJMoa2008457. https://doi.org/10.1056/NEJMoa2008457

28. MacKenzie D. Covid-19 goes global. New Sci. 2020;245(3271):7. https://doi.org/10.1016/S0262-4079(20)30424-3

29. Valencia AM. Coronavírus: por que o Equador tem o maior número de infecções por covid-19 e mortes per capita na América Latina? BBC News Brasil [Internet]. 2020 [Accessed in 2020 Jul 9]. Available in: https://www.bbc.com/portuguese/internacional-52053822 